\title{
$\mathrm{CoP}($ Community of Practice)에서 참여동기-보상 적합이 $\mathrm{CoP}$ 몰입과 지식공유활동에 미치는 영향
}

\author{
김 인 학 $^{\dagger}$ 이 지 현 $^{+\dagger} \cdot$ 고 준 $^{++\dagger} \cdot$ 김 희 웅+++
}

요 약

\begin{abstract}
기업에서 경쟁이 심화됨에 따라 경쟁력의 원천 중 하나로 주목받고 있는 것이 지식이다. 이러한 지식자원을 공유하고 활용하기 위해서 국내 외 지식경영을 수행하는 많은 기업들은 $\mathrm{CoP}(\mathrm{Community} \mathrm{of} \mathrm{Practice)를} \mathrm{운영하고} \mathrm{있다.} \mathrm{최근에} \mathrm{기업에서} \mathrm{운영하는} \mathrm{CoP}$ 는 본래의 비공식적이며 자발적인 성격에서 벗어나 조직의 전략적인 목적을 달성하기 위해 경영진들에 의해서 주도되며 공식적인 지원을 받고 있다. 하지만 기업의 이 러한 전략적 운영은 본래의 성격에서 벗어날 수 있을 뿐만 아니라 $\mathrm{CoP}$ 참여자의 자발성마저 저해하는 상황이다. 특히 $\mathrm{CoP}$ 참여자마다 개인적 특성으로 인하여 참여동기와 선호하는 보상 유형에 차이가 있기 때문에 $\mathrm{CoP}$ 운영에 있어서 많은 주의가 필요하다. 본 연구는 $\mathrm{CoP}$ 를 운영하는 기업 내 $\mathrm{CoP}$ 참여자 114 명의 설문분석을 통하여 참여동기와 보상유형을 살펴보고, 참여동기-보상 간의 적합성이 어떻게 참여자들의 $\mathrm{CoP}$ 몰입 과 지식공유활동에 영향을 끼치는 것인지를 실증분석하였다. 분석 결과, 즐거움, 호혜성, 심리적 보상, 금전·지위보상 등이 참여동기-보상 적합 에 영향을 끼치는 것으로 나타났고, 이러한 동기-보상 적합이 $\mathrm{CoP}$ 몰입을 이끌며, 궁극적으로 몰입이 지식공유활동에 긍정적 영향을 끼첬다. 즉, 내적동기, 외적동기, 내적보상 및 외적보상들이 상호 복합적으로 연관작용하여 $\mathrm{CoP}$ 몰입과 지식공유활동에 영향을 끼친다는 점에서 기업들 은 $\mathrm{CoP}$ 활성화를 위하여 동기적 측면과 보상적 측면을 충분히 고려해야 할 것이다.
\end{abstract}

키워드 : CoP, 참여동기, 보상, 몰입, 지식공유활동

\section{The Effect of Motivation-Reward Fit on Commitment and Knowledge Sharing Activities in Communities of Practice}

\author{
Inhak $\mathrm{Kim}^{\dagger} \cdot \mathrm{Ji}$-Hyeon Lee ${ }^{++} \cdot$ Joon $\mathrm{Koh}^{+++} \cdot$ Hee-Woong $\mathrm{Kim}^{++++}$
}

\begin{abstract}
As the business competition between firms is getting intense, one of the sources of competitive advantage is effectively and efficiently to create, share, and apply information/knowledge among employees. Most of the firms which conduct knowledge management are operating a Community of Practice $(\mathrm{CoP})$ in order to create, share and utilize this kind of information/knowledge resource. Recently, the $\mathrm{CoP}$ is getting out of its informal and spontaneous manner and is beginning to be led by the top management, receiving official support, in order to achieve the organization's strategic goals. However, the corporation's strategic operation of the CoP is not only against its original characteristics but also hampers the spontaneity of its participants. Every participant has different motivation to participate and different preference for reward type. This study, with the survey of 114 respondents, found that intrinsic motivation as well as extrinsic motivation significantly affect the motivation-reward fitness. Also, the motivation-reward fit was found to influence CoP commitment which ultimately leads to knowledge sharing activity in the $\mathrm{CoP}$ context. This research will help knowledge management companies to figure out how the two things of participants' motivation and their reward types can fit together, and how such fitness ultimately affects the participants' commitment and their knowledge sharing activities.
\end{abstract}

Keywords : Community of Practice, CoP, Motivation, Reward Type, Commitment, Knowledge Sharing

\section{1. 서 론}

†준 회 원: 전남대학교 경영학과 석사과정

†+ 준 회 원: 전남대학교 전자상거래협동과정

†+† 정 회 원: 전남대학교 경영학부 교수(교신저자)

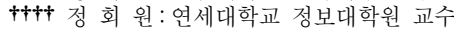

논문접수 : 2010년 3월 21일

수 정 일 : 1 차 2010년 4월 8 일

심사완료 : 2010년 4월 9일
지식은 기업의 경쟁력의 중요한 원천이다. 기업들은 이러 한 지식 경쟁력을 갖추기 위해 지식관리시스템(KMS : Knowledge Management System)을 구축하였고, 형식지를 여기에 등록하고 검증하며 활용하는 활동을 위주로 하는 지 
식경영(Knowledge Management)을 추진해 왔다. 지식경영 을 통해 지식을 필요로 하는 사람이 원하는 장소에서 적시 에 활용함으로써 업무성과를 극대화하고 기업의 경쟁력을 제고시키고자 한 것이다(이영희 외, 2007). 하지만 지식관리 시스템을 통한 기업의 지식경영은 자료를 저장하는 정도의 비효율적인 결과를 야기하였다. 이에 따라 대안적으로 많은 기업들은 효율적인 지식경영을 위해 $\mathrm{CoP}$ (Community of Practice)을 시도하였다. $\mathrm{CoP}$ 는 실행공동체라고도 종종 일컬 어지며 지식관리시스템에 단순히 자료를 등록하는 방법 대 신에 공통의 직무나 관심사를 중심으로 문제해결 또는 학습 을 위하여 공식적 또는 비공식적으로 결합된 사람들의 모임 으로(Nonaka, 1994), 형식지 중심이 아닌 암묵지를 공유할 수 있는 커뮤니티이다.

본래 $\mathrm{CoP}$ 는 비공식적이며 자발적인 성격을 지니고 있는 데 최근에 기업에서 운영하는 $\mathrm{CoP}$ 는 기업의 목적을 달성하 기위해 기업 주도의 전략적인 형태로 운영되고 있다. 하지 만 이러한 기업의 전략적인 운영은 $\mathrm{CoP}$ 본래의 성격에서 벗어날 뿐만 아니라 지나치게 조직적이고 획일적인 모습을 하고 있다. $\mathrm{CoP}$ 라는 커뮤니티는 모임과 조직이기에 앞서 여 러 명의 개인이 모여 이루어진 공동체이다. 이러한 $\mathrm{CoP}$ 를 더욱 효율적으로 운영하기 위해서는 정보시스템의 특성 외 에도 전략적 측면과 개인의 특성을 중요하게 여겨야 한다.

본 연구에서는 성공적인 $\mathrm{CoP}$ 운영을 위하여 조직이 아 닌 개인 즉, $\mathrm{CoP}$ 참여자의 참여동기와 보상유형을 알아보 고, 어떠한 참여동기에는 어떠한 보상이 적절한지를 파악하 고자 한다. 즉, 참여자의 참여동기와 보상간의 적합성을 파 악하여 어떠한 상황에서 참여자가 $\mathrm{CoP}$ 에 몰입하고 지식공 유활동을 활발하게 할 수 있는지를 실증적으로 분석하고자 한다.

\section{2. 이론적 배경}

\section{$2.1 \mathrm{COP}$ 정의와 유형}

\section{$2.1 .1 \mathrm{CoP}$ 개념 및 특징}

$\mathrm{CoP}$ (Community of Practice)라는 용어는 초보자가 전문 가에게 접근하여 자연스럽게 학습을 통해 서서히 커뮤니티 의 일원이 되어 가는 과정을 설명하기 위하여 Lave와 Wenger(1991)에 의해 처음으로 사용되었다. 이후로 지식공
유와 창조를 위해 공동 업무를 하는 직원들 간의 커뮤니티 개념으로 발전하였고, Wenger와 Snyder(2000)는 업무 수행 에 있어 문제해결을 위해 자발적이고 비공식적으로 결합된 사람들의 모임으로 정의하였다.

$\mathrm{CoP}$ 와 다른 조직의 특성을 살펴보면 다음의 <표 $1>$ 과 같다. 기업에서 지시한 목표를 달성하기 위해 통제적이고 공식적으로 운영되는 조직과는 달리 $\mathrm{CoP}$ 는 업무 실행과정 속에서 자발적으로 운영되는 비공식적인 조직으로 역량개발 과 지식창출을 목적으로 하는 모임이다.

\subsection{2 $\mathrm{CoP}$ 가 제공하는 가치(Value)}

$\mathrm{CoP}$ 는 회원들의 공통의 직무나 관심사를 바탕으로 문제 해결을 할 뿐만 아니라 $\mathrm{CoP}$ 라는 조직과 $\mathrm{CoP}$ 를 구성하는 개 인에게 유형적·무형적 가치와 결과를 가져온다. 그리고 $\mathrm{CoP}$ 가 지속되는 기간에 따라 이점과 가치에 차이가 발생한다.

$\mathrm{CoP}$ 의 가치는 지속되는 효과에 따라 장기가치(long-term value)와 단기가치(short-term value)로 나뉠 수 있고, 그에 따른 이점은 조직이나 구성원 개인 차원에서 구현된다. 구 성원들은 각자의 상황, 목표, 필요에 의해 토의하고, 공통된 당면과제를 심사숙고하며, 아이디어를 탐색하는 활발한 활 동을 통해 툴, 기준, 매뉴얼 등의 지식을 공유, 창출, 보급할 수 있다. 이것은 빠르게 정보를 탐색하고 문제를 해결하는 데 용이하며, 개인의 재능을 개발, 보충, 유지하도록 돕고 핵 심역량과 지적능력을 형성시킬 수 있다(Hoopes \& Postrel, 1999).

또한 $\mathrm{CoP}$ 는 조직 내 조언을 해주는 사람과 받는 사람간 의 관계를 조성하고, 발달시키며 서로간의 대화를 통하여 암묵적 지식을 전이시켜 공유된 조직지식을 창출해 낸다. 소비자들의 문제점에 대해 필요한 지식을 보다 빨리 공유하 고, 전달하여 그들의 필요와 문의에 보다 빨리 응답해 줄 수 있다. 기존에 있는 지식 자산들을 보다 쉽게 재사용할 수 있어 경제적이며, 구성원들이 함께 활동함으로써 친밀감 과 도전감, 편안함을 느끼는 안전한 환경을 제공함으로써 혁신적인 생산품과 서비스를 신장시키는 등 새로운 전략형 성에 이바지할 수도 있다(Lesser \& Storck, 2001).

$\mathrm{CoP}$ 가 창출하는 가치는 기준 매뉴얼, 향상된 스킬 혹은 감소된 비용 등과 같은 유형적인 측면뿐만 아니라, 신뢰도 혹은 향상된 혁신 가능성과 같은 무형적인 면도 포함한다. $\mathrm{CoP}$ 의 유형적인 측면에서 가치를 언급하는 것은 $\mathrm{CoP}$ 가 지

〈표 1〉 조직유형별 특성 비교(Wenger \& Snyder, 2000)

\begin{tabular}{|c|c|c|c|c|}
\hline 구분 & 목적 & 구성원 & 공동체 의식의 원천 & 존속기간 \\
\hline $\mathrm{CoP}$ & 구성원 역량 개발 지식창출, 공유 & 자율적 참여 & 열정, 헌신 그룹의 전문성 & 전략적 과제가 존재하는 한 지속 \\
\hline 공식팀 & 제품 생산 및 서비스 수행 & $\begin{array}{c}\text { 조직체계에 따라 같은 } \\
\text { 관리자에게 보고하는 집단 }\end{array}$ & $\begin{array}{c}\text { 요구되는 업무 및 업무상 공동 } \\
\text { 목표 }\end{array}$ & 다음 조직 재설계시 까지 \\
\hline 프로젝트팀 & 특정업무 수행 & 임원에 의해 임명된 구성원 & 프로젝트 목표와 완료일 & 프로젝트 완료시까지 지속 \\
\hline 비공식 & 정보를 획득과 전달 & 동료와 비즈니스에서 지인 & 상호 욕구 충족 & 정해진 기간 없음 \\
\hline
\end{tabular}


식을 효과적으로 공유하고 창출하고 있다는 근거를 제시한 다. 하지만 보다 큰 가치는 구성원들 간의 관계, 소속감, 신 뢰, 정체성 형성과 같은 무형적인 측면에 놓여 있다 (Wenger, Mcdermott \& Snyder, 2002).

이러한 무형적인 측면은 조직의 문화가 변화하는데 중요 한 요소들이 된다. 우선 $\mathrm{CoP}$ 활동으로 인해 관계지향적인 문화가 형성될 수 있다. $\mathrm{CoP}$ 내에서 서로의 관점을 이해하 는 동료들을 알게 되고, 관심 있는 그룹에의 소속감이 형성 되기 때문이다. 관계지향 문화는 내부조직의 통합과 유연성 을 중시하는 문화로, 무엇보다도 인간관계에 초점을 둔다. 인화·단결·협동 및 팀워크 등의 가치를 중시하고, 구성원에 대한 배려와 관심의 정도가 높으며, 인간적이고 가족적인 분위기를 창출하는 것을 특징으로 한다(김영조 \& 박상은, 2002). 구성원들 간의 소속감과 상호신뢰, 그리고 참여가 이 문화의 핵심가치가 되며, 리더의 스타일에 있어서도 참여적 이고 배려적이며, 팀워크를 통해 상호작용의 촉진자로서의 역할이 중요해진다. 둘째, 아이디어나 새로운 시각을 자유로 이 제안할 수 있는 통로인 $\mathrm{CoP}$ 가 존재함으로 인해 혁신지 향적인 문화가 형성될 수 있다. 조직 전체에 신뢰를 바탕으 로 막힘없는 의사소통과 이를 수용할 수 있는 상하간의 열 린 사고가 존재하게 된다(구자복, 2006). 또한 $\mathrm{CoP}$ 활동을 통해 정체성도 증진될 수 있는데, 이것은 특히 프랙티스(실 무) 중심의 커뮤니티 학습은 개개인의 정체성 발달과 연관 지어 이해해야 한다는 점을 강조하는 Lave와 Wenger(1991) 의 관점과 일치된다.

\section{$2.2 \mathrm{CoP}$ 참여동기 및 보상}

\section{2 .1 참여동기}

동기(Motivation)란 '한 개인으로 하여금 어떠한 행동이나 목표의 추구를 준비하는 단계' 또는 '행동을 일으키게 하고 그 행동을 지속하게 하는 심적 기제’를 뜻하는 것으로 욕구 (Need)와는 구분된다. 즉, 욕구는 각 개인의 무의식적인 심 리상태를 나타내며, 동기는 의식적인 상태로서 행동을 직접 유발시키고, 보다 상황 지향적이며, 상황 지배적인 개념이라 는 것이다. 따라서 사람들로 하여금 행동을 유발하는데 있 어서 '내재된 욕구가 활성화된 동기적인 요인'이 필요하다. 동기이론은 개개인의 정보기술 수용행위를 이해하기 위해서 사용되어진 이론으로 내적 동기와 외적 동기의 영향으로 구 별된다(이문봉, 김은정, 2005). Davis 등(1992)에 따르면 인 간의 행위에는 외적 동기와 내적 동기 모두가 작용한다고 하였다. 외적 동기는 활동 그 자체와 분리된 것으로, 어떤 활동이 유용하고 가치 있는 결과를 가져다 줄 것으로 믿을 때, 그것을 추구하는 동기를 뜻하며, 내적 동기란 활동 그 자체가 가져다 주는 순수한 즐거움을 추구하는 동기를 말한 다. 이러한 동기요인이 새로운 정보기술의 채택여부에 영향 을 준다면 인터넷을 기반으로 한 온라인 커뮤니티에 대한 태도 및 행동에도 영향을 줄 것이다.

Deci(1975)의 연구에서 외적동기는 활성의 성과로 언급하 였고, 이는 직무 성과 향상, 지불, 기타 등과 같은 활동 그
자체와 구별되는 가치 있는 결과를 달성하는데 도움을 준 다. 내적 동기는 활동을 수행하는 과정이외에 명백한 논거 가 없는 수행활동의 성과로 언급하였다. Igbaria(1995)는 행 위는 외적 동기뿐만 아니라 내적 동기에 의해서도 결정된다 고 보았다.

\section{2 .2 보 상}

조직이 제공할 수 있는 보상의 형태는 매우 복잡하다. 우 선 종업원들이 그들의 시간과 노력의 기여에 대한 교환으로 받을 수 있는 보상은 그 원천에 따라 외재적 보상과 내재적 보상으로 구분된다(Steers \& Poter, 1991). 외재적 보상은 직무자체보다는 직무를 둘러싼 환경으로부터 받는 것이며, 외부적으로 다른 누군가에 의해 제공되고 관리된다. 외재적 보상에는 급여, 상여금, 특별급여, 승진, 인정, 다른 사람으로 부터의 칭송 등이 포함된다. 반면에 내재적 보상들은 직접 적으로 직무수행과 연관된 보상으로, 어떤 과업의 수행결과 로 개인이 자신에게 제공하는 것(성취감 등)이다. 내재적 보 상들은 과업수행의 결과자체가 수혜자에게 돌아가기 때문에 자기관리(Self-administered) 보상으로 묘사된다. 내재적 보 상에는 과업의 성취감, 자율성, 직무에 대한 개인의 성장 등 이 포함된다(Steers and Poter, 1991, Daft and Steers, 1986). 또한 외재적 보상은 지식활동에 따른 금전적 보상, 승진, 인정 등의 직, 간접적인 물질적 보상을 의미한다. 내재 적 보상은 지식활동 자체에 의해 직접적으로 제공되는 가치 들에 의해 발생되며(전수환 \& 김정수, 2005), 도움의 즐거움 이나 지식에 대한 자기효능감을 포함한다(Bock et al., 2006).

조직환경에서 보상의 형태를 구분하기 위해서 쓰이는 또 다 른 차원은 $\mathrm{Katz}(1964)$ 에 의해서 강조된 전사적(systemwide), 혹은 개인적(individual) 보상이다. 전사적 보상은 조직에 의 해서 넓은 범주의 종업원 모두에게 주어지는 보상이다. 일 례로 단순히 종업원이 됨으로써 조직 내의 모두가 제공받는 의료보험 등을 들 수 있다. 반면에 개인적인 보상은 모든 범주의 개인이 아닌 특정한 개인에게 주어지는 것으로, 실 적에 따른 상여금을 예로 들 수 있다.

\subsection{3 인지평가이론(cognitive evaluation theory)}

인지평가이론(cognitive evaluation theory: CET)은 인간 이 자기행동을 스스로 결정하고 자신이 유능하다고 느끼고 싶은 기본욕구를 지닌다고 가정한다. Deci(1975)는 인간이 지니는 이 두 욕구를 자결성(self-determination theory)과 유능성(self-determination \& competence)이라고 불렀다. Deci는 인간이 이 두 가지 욕구를 충족시킬 수 있으면 어떤 과제를 수행하려는 내적동기가 유발된다고 주장한다. 그리 고 내적동기에 의한 행동이란 자결성과 유능성의 욕구에 의 해서 동기가 유발된 행동이라고 두 욕구를 중심으로 정의한 다. 그러나 동기는 관찰할 수 없는 개인의 내부과정이므로 행동의 측면에서 내적동기에 의해서 유발된 행동을 정의하 면 분명하게 외부조건과 연계성이 없는데도 실행된 행동이 
라고 정의할 수 있다.

Deci의 인지평가이론은 내적동기에 영향을 미치는 과정을 둘로 나누어서 설명한다. 먼저 자결성의 감정과 지각에 기 반을 두는 내외인과의 지각을 알아보기로 한다. 인간이 어 떤 활동을 하면 자신이 그 활동을 하게 된 이유를 추리하여 평가하게 된다. 이 때 그 활동 자체가 목적이기 때문에 자 신이 그 활동을 했다고 지각하면 그 활동이 내적동기라는 내부원인에 의해서 일어났다고 내외인과를 평가하게 된다. 반면에 어떤 보상을 얻기 위하여 활동했다고 보면 자신의 활동이 외부원인에 의해서 일어났다고 내외인과를 평가하게 된다.

금전적 보상이나 혹은 타인의 강요에 의해서 자신의 활동 이 일어난 경우에 활동의 원인이 금전이나 혹은 타인의 강 요 때문이라고 평가하게 되면 그 활동에서 외적동기체제가 가능하게 되어서 그 후에는 내적동기가 낮아진다. 이처럼 활동이 외부원인(external locus)에 의해서 일어났다고 지각 하면 내적동기체제가 외적동기체제로 옮겨지는데 이 때 인 지적 요소에서는 내외인과지각이 변화된다.

내적동기에 영향을 미치는 두 과정들 가운데 두 번째 과 정은 유능성의 감정과 지각에 기반을 둔다. 앞에서 설명한 내외인과성 지각의 과정에서 행동의 자결성이 지각되더라도 둘째 과정인 유능성의 지각에 따라서 내적동기에 영향을 받 게 된다. 즉, 두 번째 과정에서 활동을 통하여 자신이 유능 하다고 지각하지 못하게 되면 그 활동에 대한 내적동기가 저하된다. 그리고 유능성 지각은 어느 정도 자결성이 있는 상황의 맥락이 전제가 되고 있다. 예를 들어 어떤 활동에서 자신이 유능하다고 느꼈으나 만약 그 활동이 강요된 상황이 었다면 이 강요받은 상황으로 인해서 자결성의 맥락을 이루 지 못하므로 유능감은 얻더라도 활동의 자결성이 낮아서 활 동을 하려는 내적동기는 높아지지 않는다(한덕웅, 2004).

\section{3 과업-기술 적합}

과업-기술 적합(Task-Technology Fit, TTF)은 조직 내 개인의 과업과 정보기술의 적합성을 뜻하며, 과업의 특성 (Characteristics)과 정보기술의 특성이 서로 맞아야 좋은 결 과가 구현될 수 있다는 주장이다. TTF는 개인이 과업을 수 행하는 데 있어서 정보기술이 얼마나 잘 지원해주는가를 의 미한다(Goodhue \& Thompson, 1995). 이때 개인은 과업의

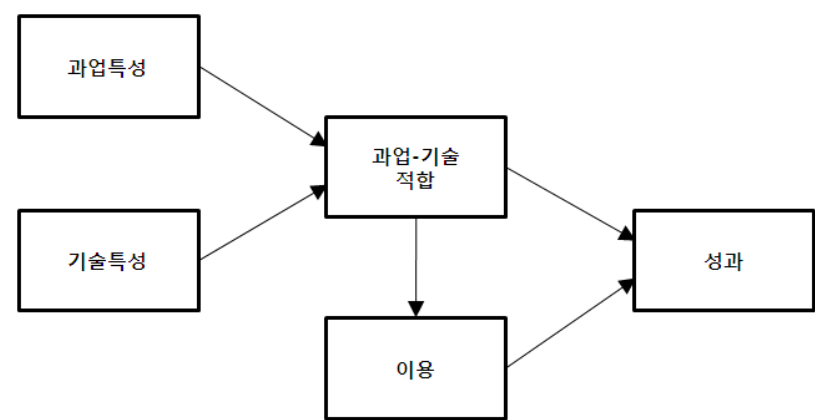

(그림 1) 과업-기술 적합 모형(Goodhue \& Thompson, 1995)
성과를 높이기 위하여 기술을 사용하는 주체로 인식된다. 따라서 과업과 기술이 적합하다는 의미는 업무를 수행할 때 기술이 업무수행에 적절한 정보를 제공해주고 과업이 잘 처 리되도록 함으로써, 개인이 최적의 의사결정을 할 수 있게 도와주고 결과적으로 높은 성과를 이끌어 낼 수 있다는 것 을 의미한다(강소라, 김민수, 양희동, 2006). 아래의 (그림 1) 은 과업-기술 적합모형을 도식화하여 나타낸 것이다. 본 연 구에서는 이러한 적합모형의 기본적인 틀을 활용하여 연구 모형을 개발코자 한다.

\section{4 몰입 및 지식공유활동}

\section{4 .1 몰입}

몰입(Commitment)은 사람과 조직의 행위를 이끄는 마음 의 상태, 개인을 특정 행위에 얽매는 심리적 힘, 혹은 행위 를 취소하거나 변화시키기 어렵게 만드는 구조적 상태 (Becker, 1960)로 정의된다. Mowday와 Steers(1979)는 커뮤 니티 몰입을 정의함에 있어서 조직의 목표와 가치관을 받아 들이고 조직을 위해 노력을 아끼지 않으며, 조직의 구성원 으로 남으려는 욕구로 정의하였다. 또한 Wiener(1982)는 조 직의 목적 및 성과달성에 부합되는 행동을 취하려는 조직구 성원의 내재화된 규범 압력으로 정의하였다.

Moorman, Zaltman and Deshpande(1992) 등은 몰입을 가 치 있는 관계를 유치하려는 지속적인 열망이라고 정의하면 서 “가치 있는 관계”라는 인식이 될 때 몰입이 존재한다고 하였다. 즉, “지속적 열망”이란 몰입된 동반자가 관계를 무한 하게 지속 유지하려는 의지와 바램으로 해석해 볼 수 있다.

Gundlach et al.(1995)의 연구에서는 몰입을 투입이나 수 단적 구성요소, 태도적 요소, 시간적 차원을 포함한다고 주 장하면서, 몰입이 수단적 몰입(instrumental commitment)에 서 태도적 의도(attitudinal intention)와 미래의 실제적 몰입 (actual commitment)으로 성장하는 자기강화 사이클을 이루 고 있다고 주장하고 있다.

\section{4 .2 지식공유활동}

일반적으로 지식창출은 지식공유의 토대 위에서 발생하는 데(Nonaka and Takeuchi, 1995), 여기서 지식공유란 “집단 성과에 영향을 주기 위한 상호간의 과정”(Nelson and Cooprider, 1996), "타부서 사람들과의 견고한 상호관계(네트 워크)를 통해 이루어지는 과정”(Hansen, 1999), 또는 “지식 구분(identification), 전수(outflow), 이동(transmission), 흡수 (inflow), 모두를 포함하는 과정”(Gupta and Govindarajan, 2000)으로 볼 수 있다. 즉 지식공유는 기본적으로 조직 내에 지식을 소유한 사람과 지식을 획득하고자 하는 사람 사이의 관계를 포함하며, 개인의 지식이 다른 사람에게 이해되고, 흡수되어, 사용될 수 있는 형태로 변환되는 과정이다(Ipe, 2003). 따라서 지식공유는 참여자들이 서로의 지식과 경험을 주고받는 상호활동으로 볼 수 있다(백윤정, 김은실, 2008). 


\section{3. 연구 모형 및 가설}

\section{1 연구 모형}

본 모형은 $\mathrm{CoP}$ 의 참여동기 및 보상이 $\mathrm{CoP}$ 의 몰입과 지 식공유활동에 어떠한 영향을 미치는지 알아보기 위한 관계 를 제시한다. $\mathrm{CoP}$ 에서 몰입과 지식공유활동에 영향을 미치 는 여러 요인이 있지만, 본 논문에서는 참여자의 참여동기 와 보상을 주요 요인으로 도입하고자 한다. 즉, $\mathrm{CoP}$ 라는 커 뮤니티는 여러 개인의 참여로 운영되는 조직이기 때문에 조 직이라는 차원도 중요하지만 개인 차원의 연구도 중요하다. 따라서 본 연구에서는 참여자들의 다양한 참여동기와 보상 유형에 대해 살펴보며, 참여자의 동기와 보상 유형이 적합 하면 $\mathrm{CoP}$ 의 몰입과 지식공유활동에 긍정적으로 영향을 미 치는지를 검증코자 한다.

본 연구에서는 선행변수와 $\mathrm{CoP}$ 의 몰입과 지식공유활동 간의 관계를 규명하기 위해 과업-기술 적합(TaskTechnology Fit, TTF) 모형을 근간으로 하였다. (그림 2)는 연구변수들 간의 관계를 다루기 위한 개념적 틀과 가설을 제시하고 있다.

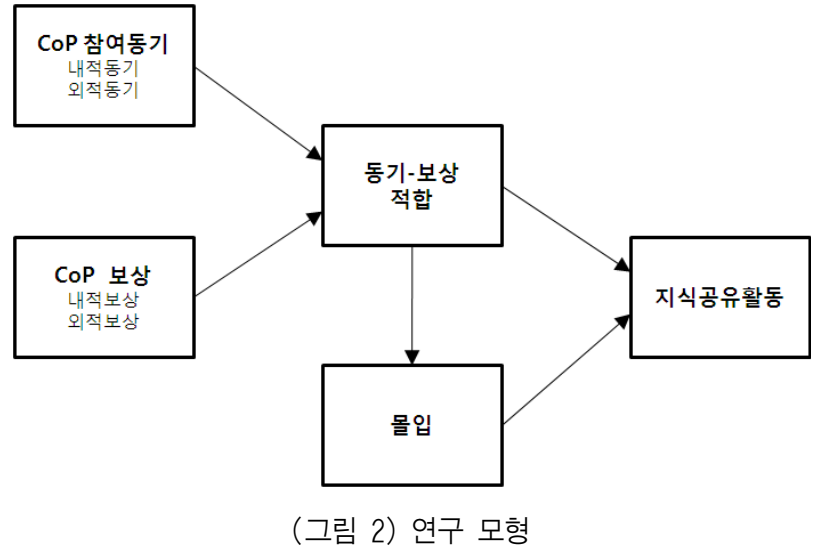

3.2 연구 가설

3.2 .1 외생요인에 관한 가설 근거

$\mathrm{CoP}$ 참여동기를 살펴보면, 참여동기는 크게 내적동기와 외적동기로 구분된다.

첫째, 내적동기에 해당되는 소속욕구, 즐거움, 이타적 즐 거움에 대해 살펴보면 다음과 같다. $\mathrm{CoP}$ 회원들은 지식공유 를 통해서 자아개념이 향상됨으로써 사회심리적인 혜택을 얻을 수 있다(Hall, 2001 ; Kollock, 1999). 사회심리적 요인 중에서 내재적 동기에 관련된 개념들이 있다. $\mathrm{CoP}$ 에서의 지 식공유에 대한 내재적 동기는 지식공유행위로 인한 혜택을 목적으로 지식공유 하는 것이 아니라, 지식공유 자체에 의 미를 두는 것이다(Frey \& Osterloh, 2001). 사회심리적 요인 으로 소속욕구(need for affiliation)가 있다. 소속욕구는 인간 이 사회적 존재로서 개인의 안전을 위해서 어떤 그룹의 일 원이 되고자 하는 내재적이고 근본적인 욕구를 말한다 (Greenberg, 1991). 이러한 소속욕구는 $\mathrm{CoP}$ 와 같은 밀접한
관계망 속에 참여함으로써 만족될 수 있다(Kadushin, 2002). 인지된 즐거움은 "온라인 커뮤니티에 참여하는 과정 속에 서 사용자가 느끼는 즐거운 감정(이문봉, 김은정, 2005)"으로 사용하였고, 인지된 즐거움의 측정항목은 문준현과 최지훈 (2003)의 연구로부터 활용하였다.

이타적 즐거움(Enjoyment in helping)은 이타주의 (altruism)에 기반을 둔 동기로서 다른 사람을 돕는 행위 자 체에서 의미를 느끼는 대표적인 내재적인 사회심리적 요인 이다(Krebs, 1975; Smith, 1981). CoP에서 다른 회원들에게 지식을 공유하는 동기가 그 회원을 돕는 행위 자체에서 얻 는 즐거움이 될 수 있다(Frey \& Osterloh, 2000; Wasko \& Faraj, 2000).

둘째, 외적동기는 이미지와 호혜성으로 구분될 수 있다. 이미지는 $\mathrm{CoP}$ 에서의 지식공유로 인해서 회원의 평판이 좋 아질 것이라는 기대감을 의미하는 외재적인 사회심리적 동 기요인이다.(전수환, 김영걸, 2006)

호혜성도 $\mathrm{CoP}$ 에서 중요한 외재적 사회심리적 동기요인이 다. 호혜성이란 어떤 $\mathrm{CoP}$ 회원이 자신의 지식을 다른 회원 들에게 제공한다면, 다음에 자신이 지식이 필요할 때 다른 회원으로부터 지식을 다시 받을 수 있을 것을 기대하는 것 을 의미한다. 온라인 커뮤니티에서도 커뮤니티 회원들의 인 지된 호혜성과 지식공유행위 간에 긍정적 관계가 존재한다 (Wasko \& Faraj, 2000; Rheingold, 2000). 더불어 지식공유 행위 뿐만 아니라 지식공유 태도에도 호혜성에 대한 기대감 이 영향을 준다는 것도 알려진 바 있다(Bock et al., 2005).

한편, $\mathrm{CoP}$ 보상유형에 대해서는 내적보상과 외적보상으 로 구분할 수 있다. 우선, 내적보상은 심리적.정신적 보상을 말한다. 예상된 인정은 $\mathrm{CoP}$ 활동을 통해서 $\mathrm{CoP}$ 회원들이 조 직으로부터 기대하는 결과를 반영하여 조직-회원 간의 관계 차원을 반영한다. 인간의 행동은 내재적인 요소뿐만 아니라 외부로부터의 자극에 의해서 영향을 받을 수 있다(Bandura, 1986). 행동에 영향을 주는 조직으로부터의 외적인 자극 중 에서 가장 일반적인 것은 조직으로부터 보상이다. Bock \& $\operatorname{Kim}(2002)$ 의 연구에서는 조직으로부터의 예상된 보상이 지 식공유에 유의한 영향을 미치는 것으로 나타났다. 또한 전 자적 지식저장소에 지식을 기여하는 행위에 조직의 보상이 영향을 미친다는 연구결과도 있다(Kankanhalli 등, 2005). 따 라서 $\mathrm{CoP}$ 에서도 지식공유에 예상된 보상이 영향을 미친다 는 가정을 할 수 있다. 다만 비공식적이고 자발적 모임인 $\mathrm{CoP}$ 의 특성을 고려했을 때 예상된 보상이 경제적 보상보다 는 지식공유 기여에 대한 조직으로부터의 인정(Recognition) 의 관점에서 파악하는 것이 적절하다(Gruen 등, 2000). 따라 서 $\mathrm{CoP}$ 에서 지식공유를 하는 회원들은 조직으로부터 인정 이라는 결과를 기대할 수 있을 것이다.

업무성취는 성취자신감(Self-efficacy)에서 이론적 근거를 찾을 수 있다. 성취자신감(Self-efficacy)이란, 자기 자신이 어떠한 상황을 해결하기 위해 필요한 조치들을 얼마나 잘 수행할 수 있느냐에 대한 개인적인 판단을 말한다(Bandura, 1977, 1986). 
둘째, 외적보상은 경제적, 물질적, 제도적 보상을 말한다. 우선 금전적 보상은 종업원의 성과에 대한 가장 큰 자극제 라고 일반적으로 받아들여진다. 금전적 보상에는 급여, 특별 급여, 상여금 등이 포함된다(Von Glinow, 1988). 한편, 지위 보상은 사회적 지위 보상을 근거로 하며 이 보상은 종업원 에게 기업 내의 다른 사람으로부터 존경과 선망을 갖게 한 다. 사회적 지위 보상은 금전적인 요소를 필요로 하지는 않 는다. 창문이 있는 사무실, 특별한 직함, 회사의 차를 내어 주는 것 등은 전형적인 사회적 지위 보상이다(Von Glinow, 1988). 또한 경력보상은 개인적인 경력의 증진과 관련이 있 으며, 이 보상은 성장과 장기적인 전망을 조명한다. 예를 들 면, 직무의 안정성, 교육훈련, 경력개발, 그리고 발전을 위한 기회 등은 모두 경력 보상이다(Von Glinow, 1988). CoP에서 내적인 동기에는 내적인 보상이 주어지고, 외적인 동기에는 외적인 보상이 주어지면 $\mathrm{CoP}$ 동기와 보상 간의 관계가 적 합할 것이라는 결과를 기대할 수 있다. 따라서 다음과 같은 가설들을 추론할 수 있다.

가설 1-1. 내적동기인 소속욕구는 동기-보상 적합에 정 $(+)$ 의 영향을 미칠 것이다.

가설 1-2. 내적동기인 즐거움은 동기-보상 적합에 정 $(+)$ 의 영향을 미칠 것이다.

가설 1-3. 내적동기인 이타적 즐거움은 동기-보상 적합에 정 $(+)$ 의 영향을 미칠 것이다.

가설 2-1. 외적동기인 이미지는 동기-보상 적합에 정 $(+)$ 의 영향을 미칠 것이다.

가설 2-2. 외적동기인 호혜성 동기-보상 적합에 정 $(+)$ 의 영향을 미칠 것이다.

가설 3. 내적보상인 심리적 보상은 동기-보상 적합에 정 $(+)$ 의 영향을 미칠 것이다.

가설 4-1. 외적보상인 금전.지위 보상은 동기-보상 적합에 정 $(+)$ 의 영향을 미칠 것이다.

가설 4-2. 외적보상인 경력보상은 동기-보상 적합에 정 $(+)$ 의 영향을 미칠 것이다.

\subsection{2 매개요인에 관한 가설 근거}

과업-기술 적합(Task-Technology Fit, TTF) 모형을 동 기-보상 적합 모형의 기반으로 삼았다. TTF 모형에서 과업 은 개인에 의해 수행되는 정보처리 행위로 폭넓게 정의되고, 기술은 개인이 과업을 수행하기 위해 사용하는 도구로 정보 기술 관련 연구에서 기술은 과업을 지원하기 위해 제공되는 유형, 무형의 도구, 사용자 지원 서비스 등을 의미한다. 개인 은 과업을 수행하기 위해 지원되는 기술을 사용하는 주체로 인식된다(유일, 김재전, 신선진, 2005). TTF 모형은 개인이 업무를 수행할 때 업무의 도구 기술과 같은 도구의 지원이 적합해야하는 것을 제안하였다. 본 연구에서는 TTF 모형에
서 과업-기술 적합하면 개인이 최적의 의사결정을 할 수 있 고 높은 도구를 가져오는 것처럼 $\mathrm{CoP}$ 에서 참여자의 동기와 보상이 적합하면 $\mathrm{CoP}$ 몰입과 지식공유활동에 긍정적인 영 향을 미칠 것이라는 결과를 기대할 수 있다. 다음의 (그림 3)은 TTF 모형을 근간으로 동기-보상 적합의 관계를 나타 내고 있다. 따라서 다음과 같은 두 가설을 제시할 수 있다.

가설 5. 동기-보상 적합은 몰입에 정 $(+)$ 의 영향을 미칠 것이다.

가설 6. 동기-보상 적합은 지식공유활동에 정 $(+)$ 의 영향 을 미칠 것이다.

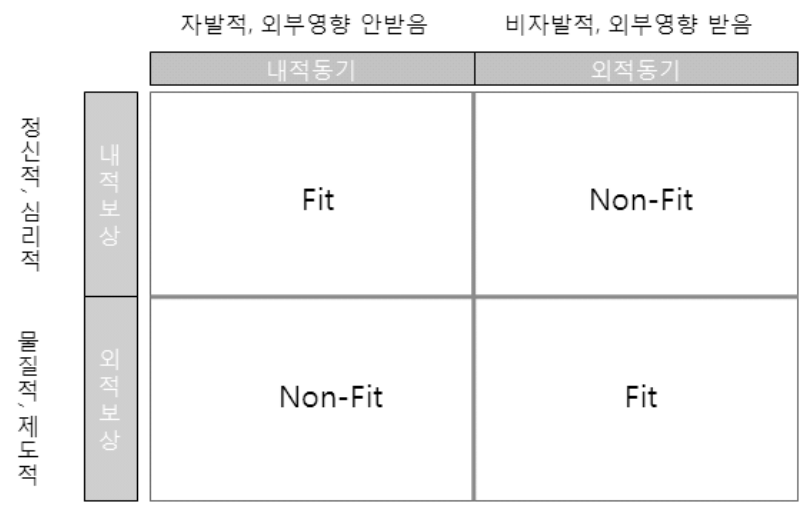

(그림 3) 동기-보상 적합

\subsection{3 결과요인에 관한 가설 근거}

몰입에 대해 Anold et al.(1998)은 조직에 대한 몰입을 개 인의 조직에 대한 집착으로 다소 추상적으로 설명하고 있으 며, Mathieu and Zajac(1990)은 조직의 목표달성을 위하여 개인이 무엇인가를 기여하고자 하는 의지로 정의하였다.

한편, 지식공유활동은 한 조직 내에서 구성원간 지식을 전수하거나 교환하는 정도로 정의된다(Bock \& Kim, 2002, Lee \& Kim, 2001, Bock et al., 2005). Grant(1996), Nonaka \& Takeuchi(1995)는 지식공유는 사람과 사람 간의 과정이 며, 지식경영의 중요한 요소라고 언급하였고, Martinez(1988) 는 개인이 갖고 있는 지식을 포함한 소장품들을 공유하게 하는 방법을 발견한 회사는 시장에서 성공할 것이며, 지식 과 경험을 공유하는 직원들은 회사에서 좀 더 가치 있고 중 요한 사람으로 대우받는다고 하였다. $\mathrm{CoP}$ 참여자의 동기와 보상이 적합하면 $\mathrm{CoP}$ 활동에 몰입을 하게 될 것이고, 몰입 은 지식공유활동에 긍정적인 영향을 미칠 것이라는 결과를 기대할 수 있다. 따라서 다음과 같은 가설을 제시한다.

가설 7. 몰입은 지식공유활동에 정 $(+)$ 의 영향을 미칠 것 이다.

3.3 변수의 조작적 정의 및 측정

실증연구를 하기 위해 개념적 정의를 측정 가능한 형태로 
변환하는 변수의 조작적 정의가 필요하다. 본 절에서는 변 수의 조작적 정의 수행을 하기 위해 각각의 변수들은 대부 분 선행연구에 검증이 되어온 측정도구를 사용하였고, 동기 -보상 적합변수는 TTF 모형에 과업-기술 적합을 바탕으로 개발되었다. 각 변수들의 조작적 정의는 다음의 <표 2>에 제시되어 있다.

〈표 2〉변수의 조작적 정의

\begin{tabular}{|c|c|c|}
\hline $\begin{array}{l}\text { 연구 } \\
\text { 변수 }\end{array}$ & 조작적 정의 & 관련연구 \\
\hline $\begin{array}{l}\text { 내적 } \\
\text { 동기 }\end{array}$ & $\begin{array}{l}\mathrm{CoP} \text { 활동 그 자체로 순수한 즐거움을 } \\
\text { 추구하는 정도 }\end{array}$ & Davis 등, 1992 \\
\hline $\begin{array}{l}\text { 외적 } \\
\text { 동기 }\end{array}$ & $\begin{array}{l}\mathrm{CoP} \text { 활동 그 자체와 분리된 것으로, 어 } \\
\text { 떤 활동이 유용하고 가치 있는 결과를 } \\
\text { 가져다 줄 것으로 믿을 때, 그것을 추 } \\
\text { 구하는 정도 }\end{array}$ & Davis 등, 1992 \\
\hline $\begin{array}{l}\text { 내적 } \\
\text { 보상 }\end{array}$ & $\begin{array}{l}\mathrm{CoP} \text { 활동의 결과로 개인이 자신에게 } \\
\text { 제공하는 보상의 정도 }\end{array}$ & $\begin{array}{l}\text { Steers and Porter, } \\
1991\end{array}$ \\
\hline $\begin{array}{l}\text { 외적 } \\
\text { 보상 }\end{array}$ & $\begin{array}{l}\mathrm{CoP} \text { 활동의 결과로 외부적으로 다른 } \\
\text { 누군가에 의해 제공, 관리되는 보상의 } \\
\text { 정도 }\end{array}$ & $\begin{array}{l}\text { Steers and Porter, } \\
1991\end{array}$ \\
\hline $\begin{array}{l}\text { 동기- } \\
\text { 보상 } \\
\text { 적합 }\end{array}$ & $\begin{array}{l}\text { 개인이 } \mathrm{CoP} \text { 활동에 참여 할 때 동기와 } \\
\text { 보상의 조화 정도 }\end{array}$ & $\begin{array}{l}\text { Goodhue and } \\
\text { Thompson, } 1995\end{array}$ \\
\hline 몰입 & $\begin{array}{l}\mathrm{CoP} \text { 활동에서 개인을 특정 행위에 얽 } \\
\text { 매는 심리적 힘의 정도 }\end{array}$ & Becker, 1960 \\
\hline $\begin{array}{l}\text { 지식 } \\
\text { 공유 } \\
\text { 활동 }\end{array}$ & $\begin{array}{l}\mathrm{CoP} \text { 조직 내에서 개인이 지식을 전수 } \\
\text { 하고 습득하며 구성원 간에 지식을 교 } \\
\text { 환하는 정도 }\end{array}$ & $\begin{array}{l}\text { Bock \& Kim, } 2002 \\
\text { Lee \& Kim, } 2001 \\
\text { Bock et al., } 2005\end{array}$ \\
\hline
\end{tabular}

\section{4. 연구방법 및 결과}

\section{1 자료의 수집 및 표본의 특성}

\section{1 .1 자료의 수집}

본 연구의 실증적인 분석을 하기 위한 자료수집의 방법으 로 설문조사를 실시하였다. 본 설문조사 기간은 2009년 10 월 12일부터 11월 7 일까지 약 4주간이며, 설문대상은 국내 기업, 의료기관, 금융기관을 중심으로 기업 내 $\mathrm{CoP}$ 참여자 를 대상으로 하였다. 설문 의뢰는 전화와 기업체를 직접 방 문하여 응답 의사를 확인하였고, 설문지 배포와 회수는 직 접 방문과 웹설문으로 실시하였다.

총 130 개의 설문지가 배포되었고, 이중에 119 개의 설문지 를 회수하여 $91.5 \%$ 의 회수율을 보였다. 회수된 설문지 중에 문항에 성실하게 응답하지 않았다고 판단되는 5 개의 설문지를 제외하여 총 114 개의 설문지가 본 연구 분석에 사용되었다.

\section{1 .2 표본의 특성}

본 연구의 표본은 기업 내의 $\mathrm{CoP}$ 참여자를 대상으로 하 였다. 본 연구에서 분석에 사용한 응답자에 관한 질문은 응 답자의 성별, 연령, 학력, 현 직급, 총 직장 경력, $\mathrm{CoP}$ 참여 기간, $\mathrm{CoP}$ 활동 주요채널 등이며, 인구통계학적 분포는 다 음의 <표 3>에 제시되어 있다.
〈표 3〉 응답자의 인구통계특성

\begin{tabular}{|c|c|c|c|}
\hline \multicolumn{2}{|c|}{ 변수명 분포 } & 표본수 & 구성비 \\
\hline \multirow{5}{*}{ 연령 } & 20대 & 26 & $22.8 \%$ \\
\hline & 30대 & 46 & $40.4 \%$ \\
\hline & 40대 & 39 & $34.2 \%$ \\
\hline & 50대 이상 & 3 & $2.6 \%$ \\
\hline & 계 & 114 & $100.0 \%$ \\
\hline \multirow{5}{*}{ 학력 } & 고졸 & 13 & $11.4 \%$ \\
\hline & 대졸(전문대 포함) & 90 & $78.9 \%$ \\
\hline & 대학원졸 & 10 & $8.8 \%$ \\
\hline & 무응답 & 1 & $0.9 \%$ \\
\hline & 계 & 114 & $100.0 \%$ \\
\hline \multirow{9}{*}{ 직급 } & 사원 & 55 & $48.2 \%$ \\
\hline & 대리/주임 & 21 & $18.4 \%$ \\
\hline & 과장 & 11 & $9.6 \%$ \\
\hline & 차장 & 14 & $12.3 \%$ \\
\hline & 부장 & 4 & $3.5 \%$ \\
\hline & 이사 이상 & 0 & $0.0 \%$ \\
\hline & 기타 & 6 & $5.3 \%$ \\
\hline & 무응답 & 3 & $2.6 \%$ \\
\hline & 계 & 114 & $100.0 \%$ \\
\hline \multirow{7}{*}{ 경력 } & 5년 이하 & 38 & $33.3 \%$ \\
\hline & 6-10년 이하 & 23 & $20.2 \%$ \\
\hline & 11-15년 이하 & 15 & $13.2 \%$ \\
\hline & 15-20년 이하 & 23 & $20.2 \%$ \\
\hline & 20년 초과 & 10 & $8.8 \%$ \\
\hline & 무응답 & 5 & $4.4 \%$ \\
\hline & 계 & 114 & $100.0 \%$ \\
\hline \multirow{3}{*}{ 성별 } & 남 & 86 & $75.4 \%$ \\
\hline & 여 & 28 & $24.6 \%$ \\
\hline & 계 & 114 & $100.0 \%$ \\
\hline \multirow{7}{*}{ 참여기간 } & 6개월 이하 & 57 & $50.0 \%$ \\
\hline & 7개월 - 12 개월 이하 & 24 & $21.1 \%$ \\
\hline & 13 개월 - 18 개월 이하 & 2 & $1.8 \%$ \\
\hline & 19 개월 - 24 개월 이하 & 9 & $7.9 \%$ \\
\hline & 25개월 이상 & 10 & $8.8 \%$ \\
\hline & 무응답 & 12 & $10.5 \%$ \\
\hline & 계 & 114 & $100.0 \%$ \\
\hline \multirow{5}{*}{$\begin{array}{l}\text { 주요 } \\
\text { 활동 } \\
\text { 채널 }\end{array}$} & 주로 온라인 & 39 & $34.2 \%$ \\
\hline & 주로 오프라인 & 26 & $22.8 \%$ \\
\hline & 온라인·오프라인 병행 & 42 & $36.8 \%$ \\
\hline & 무응답 & 7 & $6.1 \%$ \\
\hline & 계 & 114 & $100.0 \%$ \\
\hline
\end{tabular}

\section{2 자료의 기술적 및 측정도구 분석}

\section{2 .1 자료의 기술적 분석}

본 연구 모형에 포함된 변수들에 대한 기술통계량은 다음 의 <표 $4>$ 와 같다. 대부분 변수의 평균은 보통수준인 4 점 이상을 나타내고 있으나, 금전·지위 보상 변수는 평균이 3.215로 4점 이하를 나타내고 있다. 
〈표 4〉 변수의 기술통계량 $(n=114)$

\begin{tabular}{|c|c|c|c|}
\hline 범주 & 연구변수 & 평균 & 표준편차 \\
\hline \multirow{4}{*}{} & 소속 욕구 & 5.211 & 0.996 \\
\cline { 2 - 4 } & 즐거움 & 4.447 & 1.179 \\
\cline { 2 - 4 } & 이타적 즐거움 & 4.985 & 1.043 \\
\cline { 2 - 4 } & 이미지 & 4.774 & 1.111 \\
\cline { 2 - 4 } & 호혜성 & 5.208 & 1.001 \\
\cline { 2 - 4 } & 심리적 보상 & 4.696 & 1.049 \\
\cline { 2 - 4 } & 금전·지위 보상 & 3.215 & 1.103 \\
\cline { 2 - 4 } & 경력 보상 & 3.731 & 1.323 \\
\hline 매개 & 동기 - 보상 적합 & 3.985 & 1.160 \\
\hline \multirow{2}{*}{ 결과 } & 몰입 & 4.296 & 1.392 \\
\cline { 2 - 4 } & 지식공유활동 & 4.943 & 1.218 \\
\hline
\end{tabular}

\subsection{2 측정도구의 타당성 분석}

타당성은 조사자가 측정하고자 하는 개념이나 속성을 측 정하기 위하여 개발한 측정도구가 그 개념과 속성을 얼마나 정확히 측정하는가를 말한다. 아무리 측정값들의 신뢰도가 높게 나타났다 하더라도 측정된 값 자체가 다른 속성이나 다른 개념을 측정한 것이라면 의미가 없다(채서일, 2004). 본 연구에서는 측정항목의 타당성을 알아보기 위해 요인 추 출방법으로 주성분 분석(principal component analysis)을 수 행하였고, 배리맥스(varimax) 방법에 따른 직교회전 방식을 사용하였다. 요인적재치(factor loading)가 0.5 이상인 요인만

〈표 5〉 요인분석 결과

\begin{tabular}{|c|c|c|c|c|c|c|c|c|c|c|c|c|}
\hline 연구 변수 & 측정항목 & 요인1 & 요인2 & 요인3 & 요인4 & 요인5 & 요인6 & 요인7 & 요인8 & 요인9 & 요인10 & 요인11 \\
\hline \multirow{4}{*}{ 몰 입 } & COMM01 & .194 & .075 & .762 & .077 & .223 & .112 & .057 & .202 & .128 & .218 & .267 \\
\hline & COMM02 & .159 & -.003 & .801 & .013 & .192 & .032 & .064 & .046 & .080 & .253 & .155 \\
\hline & COMM03 & .244 & .073 & .822 & .059 & .098 & .048 & .071 & .223 & .039 & .201 & .180 \\
\hline & COMM04 & .190 & .056 & .797 & .149 & .077 & .171 & .134 & .273 & -.041 & .103 & .141 \\
\hline \multirow{4}{*}{$\begin{array}{l}\text { 지식 } \\
\text { 공유 } \\
\text { 활동 }\end{array}$} & SHARE01 & .143 & .072 & .534 & .136 & .244 & .125 & .070 & .215 & -.027 & .159 & .564 \\
\hline & SHARE02 & .117 & .035 & .481 & .210 & .083 & .042 & .148 & .058 & .025 & .111 & .743 \\
\hline & SHARE03 & .205 & .027 & .412 & .213 & -.003 & .055 & .140 & .098 & .023 & .161 & .722 \\
\hline & SHARE04 & .184 & -.012 & .149 & .129 & .220 & .073 & -.026 & -.058 & .109 & .429 & .664 \\
\hline \multirow{4}{*}{$\begin{array}{l}\text { 소속 } \\
\text { 욕구 }\end{array}$} & MOT01 & .271 & -.009 & .382 & .073 & .157 & -.055 & .080 & .193 & -.061 & .666 & .245 \\
\hline & MOT02 & .237 & -.004 & .161 & .345 & .263 & .053 & -.039 & .056 & .033 & .676 & .208 \\
\hline & MOT03 & .113 & -.035 & .319 & .230 & .080 & .053 & .126 & .076 & -.095 & .740 & .065 \\
\hline & MOT04 & .221 & .049 & .344 & .132 & .144 & .040 & .229 & .238 & .097 & .595 & .271 \\
\hline \multirow{4}{*}{ 즐거움 } & ENJO01 & .351 & .028 & .335 & .200 & .212 & .215 & .189 & .697 & .067 & .110 & .123 \\
\hline & ENJO02 & .343 & .005 & .348 & .186 & .194 & .182 & .157 & .707 & .057 & .160 & .074 \\
\hline & ENJO03 & .347 & .028 & .290 & .190 & .235 & .155 & .172 & .721 & .119 & .153 & .010 \\
\hline & ENJO04 & .381 & .087 & .305 & .170 & .270 & .113 & .208 & .669 & .092 & .104 & .035 \\
\hline \multirow{4}{*}{$\begin{array}{l}\text { 이타적 } \\
\text { 즐거움 }\end{array}$} & HENJ01 & .296 & .118 & .302 & .076 & .629 & .151 & .203 & .316 & .073 & .183 & .248 \\
\hline & HENJ02 & .311 & .044 & .216 & .131 & .795 & .087 & .198 & .171 & .089 & .124 & .167 \\
\hline & HENJ03 & .396 & -.069 & .230 & .272 & .683 & .082 & .132 & .184 & .129 & .234 & .018 \\
\hline & HENJ04 & .332 & .043 & .224 & .243 & .721 & .151 & .094 & .208 & .097 & .199 & .068 \\
\hline \multirow{4}{*}{ 이미지 } & IMAG01 & .299 & .249 & .042 & .147 & .115 & .033 & .691 & .247 & .111 & .196 & .224 \\
\hline & IMAG02 & .335 & .280 & .190 & .307 & .206 & .150 & .637 & .075 & .096 & -.020 & -.067 \\
\hline & IMAG03 & .330 & .229 & .164 & .184 & .143 & .108 & .721 & .193 & .096 & .130 & .101 \\
\hline & IMAG04 & .343 & .207 & .171 & .379 & .135 & .006 & .633 & .114 & .194 & .040 & .073 \\
\hline \multirow{4}{*}{ 호혜성 } & RECI01 & .248 & -.001 & .102 & .828 & .137 & .195 & .166 & .095 & -.014 & .163 & .072 \\
\hline & RECI02 & .243 & .028 & .020 & .869 & .108 & .088 & .153 & .107 & .014 & .112 & .128 \\
\hline & RECI03 & .185 & .047 & .133 & .861 & .108 & .110 & .176 & .115 & .087 & .180 & .100 \\
\hline & RECI04 & .247 & .054 & .082 & .866 & .114 & .103 & .089 & .135 & .057 & .106 & .157 \\
\hline \multirow{12}{*}{$\begin{array}{c}\text { 심리적 } \\
\text { 보상 }\end{array}$} & PSY_REW01 & .739 & .137 & .226 & .201 & .145 & .116 & .315 & .100 & .119 & .153 & -.007 \\
\hline & PSY_REW02 & .781 & .123 & .162 & .118 & .227 & .150 & .258 & .069 & .025 & .170 & .059 \\
\hline & PSY_REW03 & .823 & .157 & .207 & .126 & .150 & .185 & .196 & .070 & .097 & .153 & .027 \\
\hline & PSY_REW04 & .827 & .070 & .161 & .141 & .222 & .145 & .235 & .011 & .076 & .164 & .067 \\
\hline & PSY_REW05 & .741 & .156 & .177 & .113 & .031 & .213 & .085 & .303 & .104 & .087 & .213 \\
\hline & PSY_REW06 & .770 & .114 & .209 & .153 & -.014 & .227 & .002 & .361 & .068 & .101 & .174 \\
\hline & PSY_REW07 & .784 & .108 & .139 & .225 & .117 & .146 & -.047 & .246 & .131 & .042 & .089 \\
\hline & PSY_REW08 & .815 & .114 & .106 & .228 & .152 & .132 & .043 & .192 & .128 & .092 & .200 \\
\hline & PSY_REW09 & .645 & .241 & .120 & .194 & .329 & .176 & .341 & .133 & .134 & .059 & .058 \\
\hline & PSY_REW10 & .556 & .318 & .054 & .200 & .246 & .298 & .407 & .170 & .096 & -.032 & .120 \\
\hline & PSY_REW11 & .603 & .374 & -.004 & .195 & .236 & .180 & .292 & .152 & .093 & .184 & .069 \\
\hline & PSY_REW12 & .573 & .312 & .026 & .263 & .351 & .232 & .315 & .066 & .121 & .157 & .050 \\
\hline \multirow{6}{*}{$\begin{array}{l}\text { 금전 } \\
\text { 지위 } \\
\text { 보상 }\end{array}$} & MP_REW01 & .200 & .850 & .078 & .035 & .048 & -.006 & .042 & -.021 & .078 & -.062 & -.162 \\
\hline & MP_REW02 & .101 & .921 & .008 & .050 & .037 & -.010 & .027 & -.011 & .085 & -.088 & -.053 \\
\hline & MP_REW03 & .123 & .716 & .144 & .120 & .044 & .247 & .172 & -.085 & .188 & .043 & .108 \\
\hline & MP_REW04 & .237 & .645 & -.008 & .013 & .068 & .270 & .262 & .093 & .314 & .138 & .075 \\
\hline & MP_REW05 & .108 & .800 & .021 & -.050 & -.076 & .251 & .142 & .101 & .227 & .006 & .133 \\
\hline & MP_REW06 & .122 & .753 & -.057 & -.045 & .010 & .305 & .166 & .111 & .273 & .072 & .103 \\
\hline \multirow{3}{*}{$\begin{array}{l}\text { 경력 } \\
\text { 보상 }\end{array}$} & CA_REW01 & .139 & .252 & .100 & .061 & .061 & .192 & .109 & -.017 & .887 & -.028 & .007 \\
\hline & CA_REW02 & .181 & .324 & .030 & .031 & .107 & .035 & .030 & .121 & .861 & .004 & .054 \\
\hline & CA_REW03 & .145 & .296 & .013 & .053 & .074 & .123 & .143 & .085 & .885 & -.014 & .032 \\
\hline \multirow{4}{*}{$\begin{array}{c}\text { 동기-보상 } \\
\text { 적합 }\end{array}$} & FIT01 & .385 & .246 & .133 & .164 & .185 & .727 & .120 & .201 & .163 & .024 & .052 \\
\hline & FIT02 & .357 & .253 & .097 & .212 & .128 & .750 & .122 & .148 & .172 & .108 & .090 \\
\hline & FIT03 & .347 & .380 & .089 & .142 & .059 & .740 & .030 & .136 & .047 & -.029 & .065 \\
\hline & FIT04 & .392 & .281 & .184 & .196 & .102 & .727 & .048 & .108 & .192 & .024 & .032 \\
\hline
\end{tabular}


을 선정하였고, 중복되는 의미의 연구 변수는 제외하였다. 이와 같은 과정으로 최종적인 요인 분석 결과는 다음의 <표 5>와 같다. 분석 결과를 살펴보면, 총 57 개의 설문문항 변수들 중에 4 개의 측정항목(USEF1,USEF2, USEF3, USEF 4)을 제거하여 총 11 개의 요인들이 추출되었다. 11 개의 추출 된 요인 중에 독립변수로는 내적동기인 소속욕구, 즐거움, 이타적 즐거움과 외적동기인 이미지, 호혜성, 내적보상인 심 리적 보상, 외적보상으로는 금전·지위보상, 경력보상이 추출 되었으며, 매개변수로는 동기-보상 적합이 추출되었고, 종속 변수로는 몰입과 지식공유활동이 추출되었다. 측정항목들의 요인적재치는 대부분 0.6 이상으로 측정항목의 집중타당성이 있으며, 동시에 측정항목과 관련이 없는 요인들에 대한 판 별타당성도 만족스러운 것으로 평가되었다.

\section{2 .3 신뢰도 분석과 상관관계 분석}

신뢰도란 유사한 측정도구 혹은 동일한 측정도구를 사용 하여 동일한 개념을 반복 측정했을 때 일관성 있는 결과를 얻는 것을 말한다. 즉 신뢰도는 안정성, 일관성, 예측가능성, 정확성, 의존가능성 등으로 표현되는 개념이다(채서일, 2004). 본 연구에서는 측정항목의 내적 일관성이 있는지 알 아보기 위해 각 항목의 신뢰도를 검증하였다. 내적일관성은 동일한 개념을 측정하기 위해 여러 개의 항목을 이용할 경 우 Cronbach's alpha 계수를 이용하여 신뢰도를 저해하는 항목을 측정도구에서 제외시킴으로써 각 항목들의 내적 일 관성을 높이는 방법이다(채서일, 2004). 일반적으로 초기 연 구단계에서 alpha 계수가 0.5 0.6수준이면 신뢰도가 양호하며, 0.7이상이면 비교적 신뢰도가 높다고 볼 수 있다(Nunnally, 1978). 검증된 변수들의 항목들에 대한 Cronbach's alpha 계 수는 0.881 0.905로 나타나 변수들의 신뢰도는 비교적 높은 것으로 평가된다(표 6 참조).

또한 변수간 상관관계 분석을 실시하였다. 보통 상관계수 의 절대값이 0.2 이하이면 상관관계가 없거나 무시해도 좋 은 수준이며, 0.4 정도이면 약한 상관관계, 0.6 이상이면 강
한 상관관계로 볼 수 있다(채서일, 2004). 본 연구에서는 연 구변수들 간의 어느 정도의 관련성이 있는지 알아보기 위해 피어슨(pearson) 상관관계 분석을 실시하였으며, 그 결과는 신뢰도 분석결과와 함께 다음의 <표 $6>$ 에 제시되어 있다.

\section{3 가설의 검증 및 결과}

\subsection{1 가설 검증}

본 연구에서는 연구 모형 및 가설을 검증하기 위해 다중 회귀분석을 사용하였다. 다중회귀분석은 둘 이상의 독립변 수와 하나의 종속변수 간의 관계를 파악하기 위한 통계 분 석방법으로 본 연구에 적합한 분석 기법으로 판단되었다. 다음의 (그림 4)는 연구모형의 다중회귀분석 결과를 나타내 고 있다.

첫째, 동기와 보상 변수들이 동기-보상 적합 변수에 미치

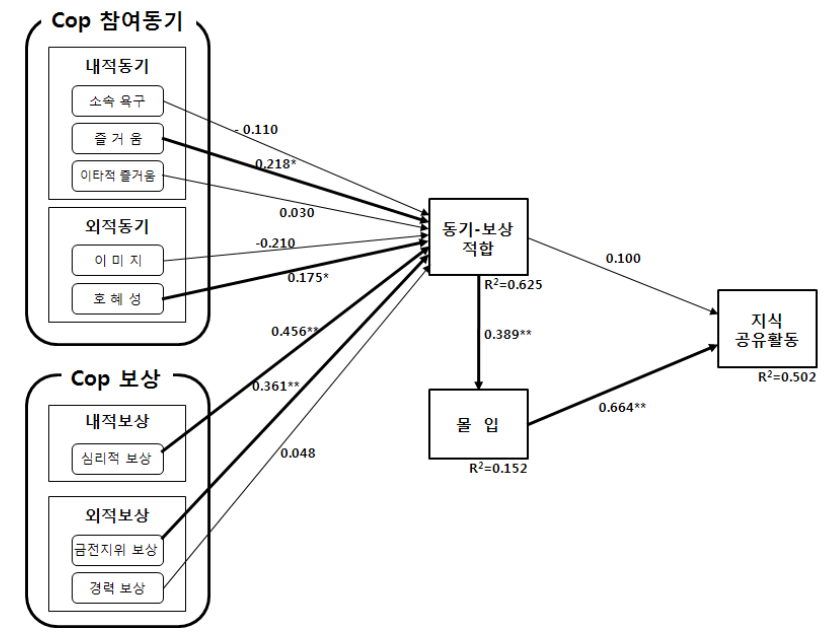

주) $1 . \Rightarrow$ : 유의적인 영향 $(* \mathrm{p}<0.05, * * \mathrm{p}<0.01)$

$\rightarrow$ : 비유의적인 영향 $(\mathrm{p}>0.05)$

2. 각 경로계수 값은 표준화된 값임.

(그림 4) 모형 분석 결과

〈표 6〉신뢰도 및 상관관계 분석결과

\begin{tabular}{|l|c|c|c|c|c|c|c|c|c|c|c|}
\hline & $\begin{array}{c}\text { 신뢰도 } \\
\text { (Cronbach a) }\end{array}$ & 1 & 2 & 3 & 4 & 5 & 6 & 7 & 8 & 9 & 10 \\
\hline 1.몰입 & 0.890 & - & & & & & & & & & \\
\hline 2.지식공유활동 & 0.891 & $.703 * *$ & - & & & & & & & & \\
\hline 3.소속옥구 & 0.891 & $.648 * *$ & $.679 * *$ & - & & & & & & & \\
\hline 4.즐거움 & 0.883 & $.644 * *$ & $.500 * *$ & $.565 * *$ & - & & & & & & \\
\hline 5.이타적 즐거움 & 0.884 & $.592 * *$ & $.544 * *$ & $.618 * *$ & $.708 * *$ & - & & & & & \\
\hline 6.이미지 & 0.885 & $.435 * *$ & $.419 * *$ & $.451 * *$ & $.601 * *$ & $.590 * *$ & - & & & & \\
\hline 7.호혜성 & 0.893 & $.341 * *$ & $.438 * *$ & $.493 * *$ & $.491 * *$ & $.505 * *$ & $.556 * *$ & - & & & \\
\hline 8.심리적 보상 & 0.881 & $.500 * *$ & $.473 * *$ & $.527 * *$ & $.697 * *$ & $.698 * *$ & $.722 * *$ & $.550 * *$ & - & & \\
\hline 9.금전·지위 보상 & 0.900 & $.200 *$ & 0.173 & 0.117 & $.249 * *$ & $.237 *$ & $.508 * *$ & 0.182 & $.473 * *$ & - & \\
\hline 10.경력 보상 & 0.905 & $.189 *$ & 0.173 & 0.107 & $.287 * *$ & $.298 * *$ & $.391 * *$ & 0.181 & $.397 * *$ & $.557 * *$ & - \\
\hline 11동기-보상 적합 & 0.888 & $.389 * *$ & $.359 * *$ & $.312 * *$ & $.559 * *$ & $.500 * *$ & $.518 * *$ & $.452 * *$ & $.706 * *$ & $.577 * *$ & $.440 * *$ \\
\hline
\end{tabular}

(주) $*: \mathrm{p}<0.05, *: \mathrm{p}<0.01$. 
〈표 7〉 동기-보상 적합에 대한 다중회귀분석 결과

\begin{tabular}{|c|c|c|c|}
\hline 독립변수 & beta & $\mathrm{t}$ & 유의확률 \\
\hline 소속욕구 & -.110 & -1.348 & .180 \\
\hline 즐거움 & .218 & 2.291 & .024 \\
\hline 이타적 즐거움 & .030 & .304 & .762 \\
\hline 이미지 & -.210 & -2.158 & .033 \\
\hline 호혜성 & .175 & 2.241 & .027 \\
\hline 심리적 보상 & .456 & 4.172 & .000 \\
\hline 금전·지위 보상 & .361 & 4.415 & .000 \\
\hline 경력 보상 & .048 & .647 & .519 \\
\hline
\end{tabular}

주) 종속변수 : 동기-보상 적합

는 인과관계를 파악하기 위한 다중회귀분석을 실시하였다. 분석결과는 <표 $7>$ 에 제시되어 있는데, 통상 beta 값은 독 립변수가 종속변수에 미치는 영향강도를 나타내고, 이 강도 가 클수록 $\mathrm{t}$ 값이 크게 나타나며 통계적으로 유의한지는 유 의확률을 기준으로 판단한다.

통상 유의확률이 0.05 이하이면 유의한 것으로 판단하는데, <표 7>에서 볼 수 있듯이 즐거움(0.218), 호혜성(0.175), 심 리적 보상(0.456), 금전·지위 보상(0.361) 등이 동기-보상 적 합 변수에 유의한 영향을 미쳤다. 또한, $\mathrm{R}^{2}$ 값 기준으로 동기 -보상 적합 변수에 대한 이들 변수들에 의한 설명력은 $62 \%$ 로 나타났다.

둘째, 동기-보상 적합 변수가 몰입 변수에 미치는 인과관 계를 파악하기 위한 회귀분석을 실시하였다. 분석결과, 동기 -보상 적합 변수는 beta값이 0.389로 나타나 몰입에 유의한
〈표 8〉 몰입 및 지식공유활동에 대한 회귀분석 결과

\begin{tabular}{|c|c|c|c|c|c|}
\hline 회귀모형 & 독립변수 & 종속변수 & beta & $\mathrm{t}$ & 유의확률 \\
\hline 1 & 동기-보상 적합 & 몰입 & .389 & 4.474 & .000 \\
\hline \multirow{2}{*}{2} & 몰입 & \multirow{2}{*}{ 지식공유활동 } & .664 & 9.132 & .000 \\
\cline { 2 - 5 } & 동기-보상 적합 & & .100 & 1.376 & .172 \\
\hline
\end{tabular}

영향을 미치는 것으로 파악되었고, 설명력( $\mathrm{R}^{2}$ 값 기준)은 약 $15 \%$ 로 나타났다. 셋째, 동기-보상 적합 변수와 몰입 변수가 지식공유활동 변수에 미치는 인과관계를 파악하기 위한 다 중회귀분석을 실시하였다. 그 결과로 동기-보상 적합의 beta 값은 0.100 , 몰입의 beta값은 0.664 를 기록하여 지식공유활동 에 모두 유의한 영향을 미친 것으로 나타났으며, $\mathrm{R}^{2}$ 값은 0.502로 두 변수에 의한 설명력이 높게 파악되었다. 이러한 결과들은 다음의 <표 8>에 제시되어 있다.

결론적으로 다중회귀분석 결과에 의하여, 총 11 개의 가설 중에서 7 개의 가설이 지지되었다. 본 연구에서 설정한 가설 에 대한 검증 결과를 요약하면 다음의 <표 9>와 같다.

\subsection{2 연구결과}

본 연구에서는 $\mathrm{CoP}$ 상황에서 참여동기-보상 적합이 $\mathrm{CoP}$ 몰입 및 지식공유활동에 미치는 영향을 밝히고자 하였다.

첫째, $\mathrm{CoP}$ 참여동기에서 내적동기인 즐거움과 외적동기 인 호혜성은 동기-보상 적합에 영향을 미치는 요인으로 밝 혀졌다. 그리고 보상에서 내적보상인 심리적 보상과 외적보 상인 금전·지위 보상이 동기-보상 적합에 영항을 미치는 요 인으로 밝혀졌다. 또한 통계적인 결과값이 참여동기보다는

〈표 9〉가설 검증 결과

\begin{tabular}{|c|c|c|c|c|}
\hline 가설 & 구성개념간 관계 & $\begin{array}{c}\text { 가설 } \\
\text { 방향 }\end{array}$ & 경로계수 & 결 과 \\
\hline $\mathrm{H} 1-1$ & 내적동기인 소속옥구 $\rightarrow$ 동기-보상 적합 & +-110 & 기 각 \\
\hline $\mathrm{H} 1-2$ & 내적동기인 즐거움 $\rightarrow$ 동기-보상 적합 & + & $0.218 *$ & 채 택 \\
\hline $\mathrm{H} 1-3$ & 내적동기인 이타적 즐거움 $\rightarrow$ 동기-보상 적합 & + & 0.030 & 기 각 \\
\hline $\mathrm{H} 2-1$ & 외적동기인 이미지 $\rightarrow$ 동기-보상 적합 & + & $0.210 *$ & 기 각 \\
\hline $\mathrm{H} 2-2$ & 외적동기인 호혜성 $\rightarrow$ 동기-보상 적합 & + & $0.175 *$ & 책 채 택 \\
\hline $\mathrm{H} 3$ & 내적보상인 심리적 보상 $\rightarrow$ 동기-보상 적합 & + & $0.361 * *$ & 채 택 \\
\hline $\mathrm{H} 4-1$ & 외적보상인 금전·지위 보상 $\rightarrow$ 동기-보상 적합 & + & 0.048 & 기 각 \\
\hline $\mathrm{H} 4-2$ & 외적보상인 경력보상 $\rightarrow$ 동기-보상 적합 & + & $0.389 * *$ & 채 택 \\
\hline $\mathrm{H} 5$ & 동기-보상 적합 $\rightarrow$ 몰입 & + & 0.100 & 기 각 \\
\hline $\mathrm{H} 6$ & 동기-보상 적합 $\rightarrow$ 지식공유활동 & + & $0.664 * *$ & 채 택 \\
\hline $\mathrm{H} 7$ & 몰입 $\rightarrow$ 지식공유활동 & + & + & + \\
\hline
\end{tabular}

주) $*: p<0.05, * *: p<0.01$. 
보상이 더 큰 영향을 미치는 것으로 나타났다. 이러한 결과 는 국내의 많은 기업들에 있어서 $\mathrm{CoP}$ 가 참여동기보다는 보 상이 중심이 되어 활성화되어 온 현실을 반영하며, $\mathrm{CoP}$ 가 주로 기업의 성과와 연결되어 전략적으로 운영되고 있음을 알 수 있다.

둘째, 참여동기-보상 적합이 지식공유활동에 직접적인 영 향을 미치는 정도보다는 참여동기-보상 적합이 몰입을 통하 여 지식공유활동에 영향을 미치는 정도가 큼을 알 수 있다. 이러한 결과는 지식공유활동의 성과를 높이기 위해서는 동 기-보상 적합이 지식공유활동에 직접적인 영향을 준다기보 다는, 몰입을 유발함으로써 지식공유활동을 활성화시킬 수 있다는 것이다. 즉, 궁극적인 $\mathrm{CoP}$ 성과 향상을 위해서는 필 수적으로 참여자의 몰입이 중요할 것이다.

셋째, $\mathrm{CoP}$ 참여동기인 소속욕구가 동기-보상 적합에 영 향을 미치는 정도는 가설 검증 결과에서는 기각이 되었지만 의미가 있다고 할 수 있다. 내적동기인 소속욕구를 좀 더 자세히 살펴보면, $\mathrm{CoP}$ 활동을 하는 구성원의 경우 회사에 대 한 소속감이나 조직에 대한 소속감 자체가 우선적인 동기가 될 수 있다. 즉, 소속감 자체로 자긍심을 느낄 수 있기 때문 에 오히려 보상과 같은 회사의 전략적 운영 방식이 개입되 면 심리적 교란이 발생하여 $\mathrm{CoP}$ 활동에 대한 흥미가 감소 하는 결과가 나올 수 있는 가능성으로 풀이된다.

본 연구결과를 종합해 보면, 내적동기와 외적동기, 내적 보상과 외적보상들이 복합적으로 연관되어 $\mathrm{CoP}$ 참여와 몰 입, 활동에 영향을 미치는 것으로 해석될 수 있다. 특히 $\mathrm{CoP}$ 동기-보상 적합을 결정지우는 핵심요인들이 내적 동 기(즐거움), 외적동기(호혜성), 내적 보상(심리적 보상), 외 적 보상(금전,지위보상)으로부터 각각 한 가지씩 골고루 도출된 점은 향후 기업들이 $\mathrm{CoP}$ 를 가꾸어 나갈 때 어떠한 요인들을 주로 고려해야 할 것인지에 대해서 함의하는 바 가 크다.

\section{5. 결 론}

\section{1 요약 및 시사점}

본 연구에서는 $\mathrm{CoP}$ 참여동기와 보상이 동기-보상 적합에 끼치는 영향을 파악하고 특히 $\mathrm{CoP}$ 동기-보상 적합이 $\mathrm{CoP}$ 몰입과 지식공유활동에 어떠한 영향을 끼치는지를 규명하고 자 하였다. 본 연구의 실증분석 결과와 시사점을 종합하면 다음과 같다.

첫째, $\mathrm{CoP}$ 참여동기의 가설은 내적동기에 해당되는 즐 거움과 외적동기에 해당되는 호혜성은 채택되고 나머지 가설들은 기각되었다. 그리고 $\mathrm{CoP}$ 보상의 가설은 내적보 상에 해당되는 심리적 보상과 외적보상에 해당되는 금전. 지위 보상은 채택되었고 나머지 가설들은 기각되었다. 즉, 참여동기와 보상 요인 모두가 동기-보상 적합에 영향을 미치지만, 참여동기에 비하여 보상적 요인이 더욱 설명력 이 크다는 것을 알 수 있다. 이로부터 우리나라의 $\mathrm{CoP}$ 환 경이 자발적인 동기보다는 보상 위주로 조성되었다는 결
론을 얻었다.

둘째, 동기-보상 적합은 지식공유활동에는 영향 정도가 약한 반면에, 몰입에는 긍정적인 영향을 미치며, 또한 몰입 은 지식공유활동에 긍정적인 영향을 미치는 것을 알 수 있 다. 이는 참여자의 동기-보상 적합이 지식공유활동에 직접 적인 영향 정도는 적지만 동기와 보상이 적합해야 참여자들 이 $\mathrm{CoP}$ 에 몰입을 할 수 있고 몰입을 통해서 지식공유활동 이 활발하게 나타난다는 것이다. 즉, $\mathrm{CoP}$ 의 성과를 제고하 기 위해서는 단순히 동기-보상 적합만으로는 부족하고 참여 자의 몰입을 유발시키기 위한 장기적인 관점에서의 접근이 필요함을 알 수 있었다. 그리고 $\mathrm{CoP}$ 에서 지식공유활동과 같 은 가시적 성과를 위해서는 $\mathrm{CoP}$ 몰입이 요구되는데, 조직문 화적 측면에서 신뢰와 같은 사회적 자본 또는 무형의 자산 을 중시할 필요가 있다(Wenger, McDermott \& Snyder, 2002).

한편, 이러한 연구결과를 토대로 $\mathrm{CoP}$ 를 운영하는 기업에 서는 $\mathrm{CoP}$ 몰입과 지식공유활동을 활성화시키기 위해서 참 여자의 개인적인 기초동기에 대한 심도 있는 파악에 앞서서 기업에서 참여자의 개인적인 특성에 알맞게 보상을 다양화 하고 이에 대한 전략적인 관리방법을 마련해야 할 것이다. 또한 $\mathrm{CoP}$ 몰입을 유발하기 위한 사회문화적 측면에서의 요 인들을 추가적으로 살펴볼 필요가 있다.

\section{2 연구의 한계 및 향후 방향}

본 연구는 $\mathrm{CoP}$ 를 실천하고 있는 국내 기업들을 대상으 로, $\mathrm{CoP}$ 가 지식공유활동의 수단으로 자리매김함에 있어 참 여동기와 보상의 중요성을 참여자 개인의 관점으로 살펴보 았다는 점에 연구의 의의가 있다. 하지만 다음과 같은 몇 가지 측면에서 한계점을 지니고 있다.

첫째, 표본 수가 114 개로 향후 연구에서는 좀 더 충분한 표본 수를 확보해야 할 것이다. 표본이 대체로 고른 연령과 직급에 분포되어 있다고 하나, 크지 않은 표본과 한정된 분 야의 $\mathrm{CoP}$ 참여자들 응답, 기업의 $\mathrm{CoP}$ 수행능력과 내재적 기업문화 등과 관련한 비교 표본 부재 등으로 인하여 일반 화를 통해 여러 기업의 상황에 적합한 길을 제안하기에는 다소 한계가 있다.

둘째, 각 변수의 특성상 시간의 흐름에 따라 효과가 달리 나타날 수 있기 때문에 종단적 연구가 바람직하나 특정시점 에서만 측정한 횡단적 연구로 수행되었다. $\mathrm{CoP}$ 특성에 비추 어 볼 때, 학습조직의 기능을 수행하고 있기에 시간의 흐름 에 따른 시간대비 성장과 학습 환경 여건에 대한 심리적 변 수들이 상당히 존재한다. 따라서 다소 오랜 시간이 걸리겠 지만 특정 시점에 따른 양자 간 비교·분석을 하여야 본 연 구에서 의도한 분석결과가 좀 더 정밀하게 나타날 수 있을 것이다.

셋째, 결과분석에서 주로 회귀분석을 사용하였는데, 모형 의 적합성을 검증하기 위한 구조방정식 모형이나 동기-보상 적합 또는 몰입의 변수들이 갖는 매개효과에 대해서도 추후 고려되어야 한다. 
넷째, 지식공유활동에는 다양하고 수많은 영향요인이 존 재할 것이다. 본 연구에서는 지식공유활동 영향요인으로 다 소 일반적인 연구변수를 설정하여 결론을 도출하였다. 향후 에는 이러한 일반적인 영향요인과 더불어 다각적이고 다차 원적인 새로운 연구변수 발굴이 필요하다. 새로운 연구변수 를 정성적인 방법 또는 탐색적 방법을 통해 발굴하여 본 연 구를 더욱 확장시켜야 할 것이다.

마지막으로 앞에서 기술됐던 연구의 한계점을 보완하여 수많은 기업들이 $\mathrm{CoP}$ 를 발달시키고 잠재적 학습능력과 지 식 데이터베이스를 구축할 수 있는 방안을 제시할 수 있는 다각적이고 심층적인 연구가 수행되어져야 할 것이다. 아울 러 조직규모와 기업 문화특성에 따른 대기업과 중소기업, 국가와 민간단체, 동종기업간의 비교, 주도권과 자발성에 따 른 조직과 개인 참여자간의 비교, $\mathrm{CoP}$ 수행역량과 기업환경 에 따른 지식생태계 네트워크상의 참여자간 심리 및 행태 연구도 필요하다.

\section{참 고 문 헌}

[1] 강소라, 김민수, 양희동. "업무-기술적합(TTF) 영향에 대한 다 차항 회귀분석과 반응표면 방법론적 접근: 그룹지원시스템 (GSS)의 경우”, 한국경영정보학회, 제 16 권 제2호, pp.47-67, 2006.

[2] 구자복. “ $\mathrm{CoP}$ 참여동기와 학습성과 인식에 관한 연구”, 한양대 학교, 2006

[3] 김영조, 박상은. “조직문화 유형, 조직문화강도와 조직성과간 의 관계에 관한 연구”, 부경대학교, 2002.

[4] 문준현, 최지훈. "가상공동체 참여동기와 공동체의식, 충성도 및 구매의도간의 관계에 관한 연구”, Information System Review, 제5권 제2호, pp.71-90, 2003.

[5] 백윤정, 김은실. "실행공동체 $(\mathrm{CoP})$ 내 지식공유의 영향요인: 구 조적 특성과 관계적 특성의 조절효과를 중심으로”, 한국지식 경영학회, 제9권 제2호, pp.63-87, 2008.

[6] 유일, 김재전, 신선진. “고객센터의 과업-매체적합과 사용자 만 족에 관한 연구”, 경영정보학연구, 제 15 권 제4호, pp.61-88, 2005.

[7] 이문봉, 김은정. "온라인 커뮤니티에서 개인의 참여 동기와 사 회적 영향 요인이 몰입에 미치는 영향”, 정보시스템연구, 제 14 권 제2호, pp.191-214, 2005.

[8] 이영희, 이봉규, 송인국, 이정우, 정승렬. "지식경영의 추진전략 이 성과에 미치는 영향에 관한 연구”, 정보처리학회논문지D, 제14권 제7호, pp.791-800, 2007.

[9] 전수환, 김영걸. " $\mathrm{CoP}$ 유형에 따른 지식공유 태도 및 의도 형 성”, 제 16 회 한국지식경영학회 춘계학술심포지엄, 2006.

[10] 전수환, 김정수. " $\mathrm{CoP}$ 에서의 지식공유행위에 대한 영향요인: Triandis 모형을 근간으로”, 경영학연구, 제34권 제6호, pp.1667-1693, 2005.

[11] 채서일. '사회과학조사방법론', 학현사, 2004.
[12] 한덕웅. '인간의 동기심리', 박영사, 2004.

[13] A. Bandura, 'Social Foundations of Thought and Action', Prentice-Hall, 1986.

[14] H. S. Becker, "Notes on the Concept of Commitment," The American Journal of Sociology, Vol.66, pp.32-40, 1960.

[15] G. W. Bock and Y. G. Kim. "Breaking the Myths of Rewards: An Exploratory study of Attitudes About Knowledge Sharing," Information Resources Management Journal, Vol.15, No.2, pp.14-21, 2002.

[16] G. W. Bock, Y. G. Kim, R. W. Zmud, and J. N. Lee, "Behavioral Intention Formation in Knowledge Sharing: Examining the Roles of Extrinsic Motivators, SocialPsychological Forces, and Organization Climate," MIS Quarterly, Vol.29, No.1, pp.87-111, 2005.

[17] R. L. Daft and R. M. Steers, 'Organizations A Micro/Macro approach', Scott, Foresman and Company, 1986.

[18] F. D. Davis, R. P. Bagozzi, and P. R. Warshaw, "Extrinsic and Intrinsic Motivation to Use Computers in the Workplace," Journal of Applied Social Psychology, Vol.22, No.14, pp.1111-1132, 1992.

[19] F. D. Davis, "Perceived Usefulness, Perceived Ease of Use and User Acceptance of Information Technology," MIS Quarterly, Vol.13, No.3, pp.319-339, 1989.

[20] E. L. Deci, 'Intrinsic Motivation', New York Plenum, 1975.

[21] B. S. Frey and M. Osterloh, 'Successful Management by Motivation: Balancing Intrinsic and Extrinsic Incentives', Springer-Verlag Berlin Heidelberg, 2002.

[22] M. A. Von Glinow, 'The New Professionals: Managing Today's High-Tech Employees,' University of Southern California, 1988.

[23] D. L. Goodhue and R. L. Thompson, "Task-Technology Fit and Individual Performance," MIS Quarterly, Vol.19, No.2, 1995, pp.213-236.

[24] J. Greenberg, 'Oedipus and Beyond; A Clinical Theory', Harvard University Press, 1991.

[25] T. W. Gruen, J. O. Summers and F. Acito, "Relationship Marketing Activities, Commitment, and Membership Behaviors in Professional Associations," Journal of Marketing, Vol.64, pp.34-49, 2000.

[26] G. T. Gundlach, R. S. Achrol, and J. T. Mentzer, "The Structure of Commitment in Exchange," Journal of Marketing, Vol.59, pp.78-92, 1995.

[27] A. K. Gupta and V. Govindarajan, "Knowledge Management's Social Dimension: Lessons from Nucor Steel," Sloan Management Review, pp.71-80, 2000.

[28] H. Hall, "Social Exchange for Knowledge Exchange, Paper Presented at Managing Knowledge Management: Convertsations and Critiques," University of Leicester Management 
Center, April, pp.10-11, 2001

[29] M. T. Hansen, "The Search-Transfer Problem: The Role of Weak Ties in Sharing Knowledge across Organization Subunits," Administrative Science Quarterly, Vol.44, pp.82111, 1999.

[30] D. G. Hoopes and S. Postrel, "Shared Knowledge, Glitches and Product Development Performance," Strategic Management Journal, Vol.20, pp.837-865, 1999.

[31] M. Igbaria, T. Guimaraes and G. Davis, "Testing the Determinant of Microcomputer Usage via a Structural Equation Model," Journal of Management Information System, Vol.11, No.4, Spring, pp.87-114, 1995.

[32] M. Ipe, "Knowledge Sharing in Organizations: A Conceptual Framework," Human Resource Development Review, Vol.2, No.4, pp.337-359, 2003.

[33] C. Kadushin, "The Motivational Foundation of Social Network," Social Networks, Vol.24, pp.77-91, 2002.

[34] A. Kankanhalli, B. C. Y. Tan and K. K. Wei, "Contributing Knowledge to Electronic Knowledge Repositories: An Empirical Investigation," MIS Quarterly, Vol.29, No.1, pp.113-143, 2005.

[35] D. Katz, "The Motivational Basis of Organization Behavior," Behavioral Science, Vol.9, No.2, pp.131-146, 1964.

[36] P. Kollock, 'The Economies of Online Cooperation: Gifts and Public Goods in Cyberspace, in Communities in Cyberspace', M. Smith and P. Kollock ED., Routledge, pp.220-239, 1999.

[37] J. Lave and E. Wenger, 'Situated Learning: Legitimate Peripheral Participation', Cambridge University Press, 1991.

[38] E. L. Lesser and J. Storck, "Community of Practice and Organizational Performance," IBM Systems Journal, Vol.40, No.4, pp.831-841, 2001.

[39] J. E. Mathieu and D. E. Zajac, "A Review and Meta-Analysis of the Antecedents, Correlates, and Consequences of Organizational Commitment," Psychological Bulletin, Vol.108, pp.171-194, 1990.

[40] C. Moorman and G. Zaltman, "Relationships Between Providers and Users of Market," Journal of Marketing Research, Vol.29, No.3, 1992.

[41] R. T. Mowday and R. M. Steers, "The Measurement of Organizational Commitment," Journal of Vocational Behavior, Vol.14, pp.223-247, 1979.

[42] K. M. Nelson and J. G. Cooprider, "The Contribution of Shared Knowledge to IS Group Performance," MIS Quarterly, December, pp.409-429, 1996.

[43] L. Nonaka and H. Takeuchi, 'The Knowledge Creating Company', Oxford University Press, 1995.

[44] J. C. Nunnally, 'Psychometric Theory', McGraw-Hill, 1978.

[45] R. M. Steers and L. W. Poter, 'Motivation and Work
Behavior', McGraw-Hill Inc, Fifth ED., 1991.

[46] M. M. Wasko and S. Faraj, "It is What One Does: Why People Participate and Help Others in Electronic Communities of Practice," Journal of Strategic Information Systems, Vol.9, pp.155-173, 2000.

[47] E. Wenger and W. M. Snyder, "Communities of Practice: The Organizational Frontier," Harvard Business Review, Vol.78, No.1, pp.139-145, 2000

[48] E. Wenger, R. McDermott, and W. Snyder, 'Cultivating Communities of Practice: a Guide to Managing Knowledge', Harvard Business School Press, 2002.

[49] Y. Wiener, "Commitment in Organizations: A Normative View," Academy of Management Review, Vol.7 No.3, pp.418-428, 1982.

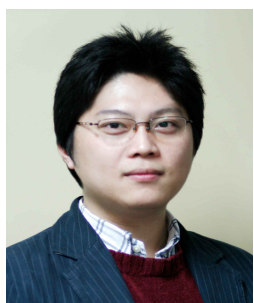

김 인 학

e-mail : kiminhak@gmail.com 2007년 전남대학교 경영학부(학사) 현 전남대학교 경영학과 석사과정 관심분야 : 지식경영, 지식/정보 모델링, 인공신경망 등

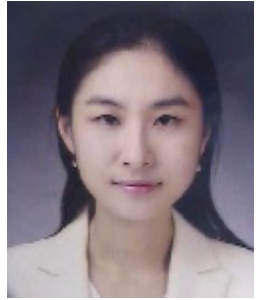

이 지 현

e-mail : jhparan@nate.com 2002년 조선대학교 국어국문학과(학사) 2010년 전남대학교 전자상거래협동과정 (석사) 관심분야 : 지식경영, $\mathrm{e}^{-ㅂ ㅣ ㅈ ㅡ ㄴ ㅣ ㅅ ㅡ ~ ㄷ ㅡ ㅇ ~}$

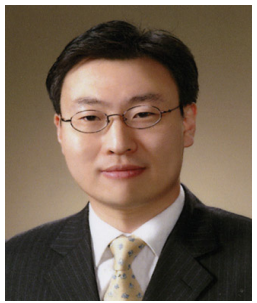

\section{고 준}

e-mail :kjoon@chonnam.ac.kr 1996년 KAIST 산업경영학과 졸업(학사) 1998년 KAIST 테크노경영대학원(공학석사) 2003년 KAIST 테크노경영대학원(공학박사) 2003년 2004년 삼성전자반도체 경영혁신 팀 과장

2005년 현 재 전남대학교 경영학부 교수 관심분야: 지식경영, 커뮤니티, $\mathrm{e}^{-}$비즈니스 등 


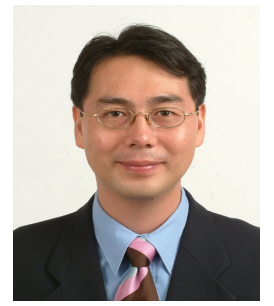

\section{김 희 웅}

e-mail :kimhw@yonsei.ac.kr

홈페이지 : http://melab.yonsei.ac.kr/

1992년 POSTECH 산업공학과(학사)

1994년 POSTECH 대학원(석사)

1998년 KAIST테크노경영 대학원(박사)

2002년 2009년 National University of

Singapore 교수

2009년 현 재 연세대학교 정보대학원 교수

관심분야: 디지털 비즈니스, 정보시스템 관리 등 